\title{
Pengaruh Kompetensi Guru Terhadap Prestasi Siswa Pada SMK Pariwisata YAPPMI Jatibarang Indramayu
}

\author{
Meddy Nurpratama, Agus Yudianto* \\ Universitas Wiralodra Indramayu
}

\begin{abstract}
The world of education today is growing rapidly and the problem of education is increasingly complex which continues to struggle for challenges that are left unchecked just like that, but it requires constructive thinking in order to achieve good quality. The problem in question is the teacher's teaching competence. The problem of education and teaching is a fairly complex problem where many factors influence it. One of these factors is the teacher. The teacher is a teaching component that plays an important and major role, because the teaching and learning process is very much determined by the teacher factor. The task of the teacher is to deliver the subject matter to students through communication interactions in the teaching and learning process, where the success of the teacher in delivering the material is very dependent on the smoothness of communication interactions that have an effect on the message given by the teacher The problem of education and teaching is a fairly complex problem where many factors influence it. One of these factors is the teacher. The teacher is a teaching component that plays an important and major role, because the teaching and learning process is very much determined by the teacher factor. The task of the teacher is to deliver the subject matter to students through communication interactions in the teaching and learning process, where the success of the teacher in delivering the material is very dependent on the smoothness of communication interactions that have an effect on the message given by the teacher. The competency of teachers at the YAPPMI Jatibarang Indramayu Tourism Vocational School is in very good condition. The results of the recapitulation of the respondent's score on the competence of teachers at the YAPPMI Jatibarang Indramayu Vocational School of Tourism are 993, the data is in a strongly agreed area $(945-1125=$ strongly agree), Regression Analysis. The results of data collection will be collected for each variable as a value for each respondent and can be calculated through the SPSS program. The method of analyzing data uses statistical calculations and uses the SPSS version 23 program to test the predetermined hypothesis whether it can be accepted or rejected. In this calculation the statistical calculations use a simple regression analysis model: $\mathrm{Y}=\mathrm{a} \mathrm{bX}+\mathrm{e}$. The achievement of students and employees at SMK Pariwisata YAPPMI Jatibarang Indramayu is in very good condition. The results of the recapitulation of scores of respondents' answers regarding student achievement at SMK Pariwisata YAPPMI Jatibarang Indramayu are 653 the data is in very good areas $(630-750=$ strongly agree). The results of statistical tests on the teacher competency variable on student achievement indicate that the $\mathrm{R}$ Square value is 0.220 , or $22 \%$, which means that there is an effect of teacher competence on student achievement and the remaining $78 \%$ is a variable outside the study. The value of the teacher competency $t(X)$ is greater than the $t$ table $(2.790>2.064)$ or the significance level of the $t$ count is smaller than the alpha value $(0.010<0.05)$, thus that there is acceptance of $\mathrm{H} 0$ or acceptance of $\mathrm{Ha}$ which means it shows the influence of the teacher competency variable $(\mathrm{X})$ positively and significantly towards the student achievement variable $(\mathrm{Y})$.
\end{abstract}

\section{ABSTRAK}

Dunia pendidikan saat ini sedang berkembang pesat dan masalah pendidikan yang semakin kompleks terus memperjuangkan tantangan yang dibiarkan begitu saja. Namun diperlukan pemikiran yang konstruktif agar dapat mencapai kualitas yang baik. Masalah yang dimaksud adalah kompetensi mengajar guru. Masalah pendidikan dan pengajaran merupakan masalah yang cukup kompleks dimana banyak faktor yang mempengaruhinya. Salah satu faktor tersebut adalah guru. Guru merupakan salah satu komponen pengajaran yang memegang peranan penting dan utama, karena proses belajar mengajar sangat ditentukan oleh faktor guru. Tugas guru adalah menyampaikan materi pelajaran kepada siswa melalui interaksi komunikasi dalam proses belajar mengajar, dimana keberhasilan guru dalam menyampaikan materi sangat bergantung pada kelancaran interaksi komunikasi yang berpengaruh pada pesan yang diberikan oleh guru. Masalah pendidikan dan pengajaran merupakan masalah yang cukup kompleks dimana banyak faktor yang mempengaruhinya. Salah satu faktor tersebut adalah guru. Guru merupakan salah satu komponen pengajaran yang memegang peranan penting dan utama, karena proses belajar mengajar sangat ditentukan oleh faktor guru. Tugas

\section{CONTACT}

meddynurpratamafe@unwir.ac.id

KEYWORDS

Kompetensi Guru, Prestasi Siswa, SMK Pariwisata

Received: 28/02/2021

Revised: 25/03/2021

Accepted: 30/03/2021

Online: 25/04/2021

Published: 30/04/2021

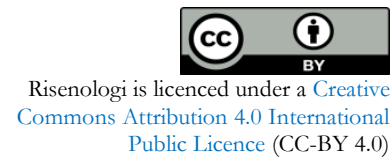


guru adalah menyampaikan materi pelajaran kepada siswa melalui interaksi komunikasi dalam proses belajar mengajar, dimana keberhasilan guru dalam menyampaikan materi sangat bergantung pada kelancaran interaksi komunikasi yang berpengaruh pada pesan yang diberikan. oleh guru. Kompetensi guru di SMK Pariwisata YAPPMI Jatibarang Indramayu dalam kondisi sangat baik. Hasil rekapitulasi skor responden tentang kompetensi guru di SMK Pariwisata YAPPMI Jatibarang Indramayu adalah 993, data berada pada daerah sangat setuju (945 - 1125 = sangat setuju), Analisis Regresi. Hasil pendataan akan dikumpulkan untuk masing-masing variabel sebagai nilai untuk masing-masing responden dan dapat dihitung melalui program SPSS. Metode analisis data menggunakan perhitungan statistik dan menggunakan program SPSS versi 23 untuk menguji hipotesis yang telah ditentukan apakah dapat diterima atau ditolak. Dalam perhitungan ini perhitungan statistik menggunakan model analisis regresi sederhana: $\mathrm{Y}=\mathrm{a} \mathrm{bX}+\mathrm{e}$. Prestasi siswa dan karyawan di SMK Pariwisata YAPPMI Jatibarang Indramayu dalam kondisi sangat baik. Hasil rekapitulasi skor jawaban responden mengenai prestasi belajar siswa di SMK Pariwisata YAPPMI Jatibarang Indramayu sebanyak 653 data berada pada daerah sangat baik $(630$ - $750=$ sangat setuju). Hasil uji statistik variabel kompetensi guru terhadap prestasi belajar siswa menunjukkan nilai R Square sebesar 0,220 atau 22\% yang artinya terdapat pengaruh kompetensi guru terhadap prestasi belajar siswa dan sisanya $78 \%$ merupakan variabel di luar pembelajaran. . Nilai kompetensi guru $t(X)$ lebih besar dari tabel $(2,790>2,064)$ atau tingkat signifikansi t hitung lebih kecil dari nilai alpha $(0,010<0,05)$, sehingga terdapat penerimaan $\mathrm{H} 0$ atau penerimaan. Ha yang artinya menunjukkan pengaruh variabel kompetensi guru $(\mathrm{X})$ secara positif dan signifikan terhadap variabel prestasi belajar siswa $(\mathrm{Y})$.

\section{INTRODUCTION}

Dunia pendidikan dewasa ini berkembang semakin pesat dan semakin kompleksnya persoalan pendidikan yang dihadapi bukanlah tantangan yang dibiarkan. Bagaimana kompetensi guru yang ada di SMK Pariwisata YAPPMI Jatibarang Kabupaten Indramayu. Seorang guru perlu memiliki kepribadian, menguasai bahan pelajaran dan menguasai cara-cara mengajar sebagai kompetensinya. Tanpa hal tersebut guru akan gagal dalam melaksanakan tugasnya. Jadi kompetensi mengajar harus dimilki oleh seorang guru yang merupakan keterampilan dalam mengelola kegiatan pendidikan. Dengan demikian guru yang mempunyai kompetensi mengajar mampu menciptakan lingkungan belajar yang efektif dan menyenangkan serta lebih mampu mengelola kelasnya sehingga hasil belajar siswa berada pada tingkat optimal.

Guru profesional adalah kemampuan seorang guru untuk melaksanakan tugas pokoknya sebagai seorang pendidik dan pengajar yang meliputi kemampuan dalam merencanakan, menjalankan, dan mengevaluasi hasil pembelajaran. Pendidikan berintikan antara pendidik (guru) dan pesertan didik (siswa) untuk mencapai tujuantujuan pendidikan. Dalam situasi tertentu tugas guru dapat diwakilkan atau dibantu oleh unsur lain seperti media teknologi, tetapi tidak dapat digantikan. Mendidik adalah pekerjaan profesional, oleh karena itu, guru sebagai pelaku utama pendidikan merupakan pendidik profesional. Sebagai pendidik profesional guru bukan saja dituntut melaksanakan tugasnya secara profesional, tetapi juga harus memiliki pengetahuan dan kemampuan professional. Kemudian Kompetensi kepribadian sangat besar pengaruhnya terhadap pertumbuhan dan perkembanganpribadi siswa. Menurut Musfah (2011:42) "Kompetensi kepribadian adalah kemampuan kepribadian yangberakhlak mulia, mantap, stabil dan dewasa, arif dan berwibawa, menjadi teladan, dan mengevaluasikinerja sendiri”.

Prestasi merupakan hasil yang dicapai seseorang ketika mengerjakan tugas dan kegiatan tertentu. Prestasi akademik adalah hasil belajar yang diperoleh dari kegiatan pembelajaran di sekolah atau di perguruan tinggi yang bersifat kongnitif dan biasanya ditentukan melalui pengukuran dan penilaian. Sementara prestasi belajar adalah penguasan pengetahuan dan keterampilan yang dikembangkan oleh mata pelajaran, lazimnya ditunjukan dengan nilai tes atau angka nilai yang diberika oleh guru.

Menurut Hamdani (2011:138) "Prestasi belajar adalah hasil yang diperoleh berupa kesan-kesanyang mengakibatkan perubahan dalam diri individu sebagai hasil dari aktivitas dalam belajar”. Sedangkan Cogen (2006: 32) "Prestasi belajar adalah tingkat keberhasilan siswa dalam mempelajari materi pelajarandi sekolah yang diperoleh dari hasil test mengenai sejumlah materi pelajaran tertentu.

Pada observasi sebelumnya di SMK Pariwisata YAPPMI Jatibarang Kabupaten Indramayu, peneliti melihat kompetensi pedagogik yang dimiliki oleh guru-guru di sekolah tersebut adalah : guru memfasilitasi pengembangan potensi peserta didik dan diadakannya kegiatan extrakulikuler setiap hari sabtu, menguasai karakteristik peserta didik, dan menyelenggarakan pembelajaran yang mendidik, serta melakukan evaluasi pada akhir pembelajaran. Bagaimana prestasi siswa yang ada di SMK Pariwisata YAPPMI Jatibarang Kabupaten Indramayu .Apakah terdapat pengaruh yang signifikan antara kompetensi guru terhadap prestasi siswa di SMK Pariwisata YAPPMI Jatibarang Kabupaten Indramayu. Kompetensi guru merupakan kemampuan yang harus dimiliki guru mulai dari tingkat pra 
sekolah, tingkat dasar, dan tingkat menengah dapat dikategorikan pada dua kategori; kompetensi umum dan kompetensi khusus.Kompetensi umum adalah kemampuan dan keahlian yang harus dimiliki oleh setiap guru pada setiap jenjang pendidikan.Sedangkan kompetensi khusus adalah kemampuan dan keahlian yang harus dimiliki secara khusus oleh tenaga pendidik tertentu sesuai dengan jenjang dan jenis pendidikan yang ditekuni. Setiap proses pendidikan di sekolah kegiatan belajar mengajar merupakan kegiatan yang paling pokok dimana dengan berjalannya kegiatan belajar di sekolah dapat mencerminkan berjalannya proses pendidikan. Penilaian merupakan salah satu cerminan dari hasil kegiatan belajar di sekolah yang dicapai peserta didik dalam menempuh proses pembelajaran. Prestasi belajar peserta didik dapat diukur dari pekerjaan peserta didik selama satu semester, yang pada akhirnya dituangkan dengan nilai yang berbentuk angka-angka. Angka tersebut merupakan cerminan atau ukuran dari hasil yang dicapai peserta didik dalam belajar. Faktor yang berpengaruh dalam menentukan prestasi belajar salah satunya yaitu guru. Sementara Hanger (dalam Suprihatiningrum 2013:100) menyatakan kompetensi merupakanbentuk perspektif dari penampilan dan tingkah laku atau kapasitas seseorang dalam bekerja danbertingkah laku. Dalam Undang-Undang Republik Indonesia Nomor 14 Tahun 2005 Tentang Guru dan Dosen dijelaskan bahwa "Kompetensi adalah seperangkat pengetahuan, keterampilan, dan perilaku yangharus dimilliki, dihayati, dan dikuasai oleh guru atau dosen dalam melaksanakan tugas keprofesionalan".

Guru dan siswa adalah dua komponen yang tidak dapat dipisahkan dalam dunia pendidikan. Guru bertugasmendidiksetiap siswa menjadi lebih produktif. Guru juga memiliki peranan yang sangat penting karenamemegang pendidikan dan pengajaran di sekolah sehingga dapat menjadi salah satu faktor penentukeberhasilan siswa. Jika kompetensi guru rendah maka prestasi belajar siswa pun rendah, begitu jugasebaliknya (dalam Jejen Musfah 2011:3). Berikutnya Menurut Sukmadinata (2006:197) "Guru harus mengenal dan memahami siswa dengan baik,memahami tahap perkembangan yang telah dicapainya, kemampuannya, keunggulan dan kekurangannya,hambatan yang dihadapi serta faktor dominan yang mempengaruhinya". Dalam Peraturan MenteriNasional RI Nomor 16 Tahun 2007 tentang standar Kompetensi Akademik dan Kompetensi Gurumenyebutkan bahwa "Guru harus menguasai empat kompetensi utama, yaitu pedagogik, kepribadiansosial, dan profesional yang terintegrasi dalam kinerja guru.

Istilah prestasi belajar terdiri atas dua kata yaitu prestasi dan belajar.Prestasi selalu dengan pelaksanaan suatu kegiatan atau aktivitas. Prestasi belajar merupak hal yang tidak dapat dipisahkan dari kegiatan belajar, karena kegiatan belajar merupakan proses, sedangka prestasi belajar merupakan hasil dari proses belajar.

Menurut Hetika (2008:23) , Prestasi Belajar adalah pencapaian atau kecakapan yang dinampakkan dalam keahlian atau kumpulan pengetahuan. Sedangkan Harjati (2008:43), menyatakan bahwa Prestasi merupakan hasil usaha yang dilakukan dam menghasilkan perubahan yang dinyatakan dalam bentuk simbol untuk menunjukkan kemampuan pencapaian dalam hasil kerja dalam waktu tertentu. Prestasi belajar merupakan hal yang tidak dapat dipisahkan dari kegiatan belajar karena prestasi belajar merupakan output dari proses belajar seperti halnya yang dikatakan oleh Tohirin (2008:151), "Prestasi belajar diperoleh dari apa yang telah dicapai oleh siswa setelah siswa melakukan kegiatan belajar". Keberhasilan seorang siswa dalam belajar dapat dilihat dari prestasi belajar siswa yang bersangkutan. Menurut Sumadi Suryabrata (2015:297) , prestasi belajar sebagai nilai, merupakan perumusan akhir yang diberikan oleh guru dalam hal kemajuan prestasi belajar yang telah dicapai siswa selama waktu tertentu.

\section{METHODS}

Tujuan penelitian yang hendak dicapai dalam penelitian ini adalah: Untuk mengetahui bagaimana kompetensi guru di SMK Pariwisata YAPPMI Jatibarang Kabupaten Indramayu.Untuk mengetahui bagaimana prestasi siswa di SMK Pariwisata YAPPMI Jatibarang Kabupaten Indramayu.Untuk mengetahuiapakah terdapat pengaruh yang signifikan antara kompetensi guru terhadap prestasi siswa di SMK Pariwisata YAPPMI Jatibarang Kabupaten Indramayu.

1. Populasi

Pengertian populasi menurut Sugiyono (2014: 72) adalah "Wilayah generalisasi yang terdiri atas objek-subjek yang mempunyai kuantitas dan karakteristik tertentu yang ditetapkan oleh peneliti untuk dipelajari dan kemudian ditarik kesimpulannya".

Suharsimi Arikunto (2012:102) berpendapat bahwa yang dimaksud dengan populasi adalah keseluruhan objek penelitian. Dari pendapat yang dikemukakan di atas, maka peneliti dapat mengambil suatu kesimpulan bahwa yang dimaksud dengan populasi adalah keseluruhan objek yang akan diteliti. Oleh karena itu, Populasi dalam penelitian ini adalah tenaga pendidik dan kependidikan di SMK Pariwisata YAPPMI Jatibarang berjumlah 25 orang. 
2. Sampel

Sampel menurut Sugiyono (2014:73) adalah "sebagian dari jumlah dan karakteristik yang dimiliki populasi tersebut". Lebih khusus lagi penelitian ini menggunakan teknik total sampling yaitu pengambilan sampel atas kecilnya populasi. Dalam hal ini peneliti mengambil sampel sebesar 25 guru dan pegawai. Hal ini sesuai dengan pendapat yang dikemukakan oleh Suharsimi Arikunto Suharsimi Arikunto (2012:103) yang mengemukakan bahwa: "Apabila subjeknya kurang dari 100, lebih baik diambil semua sehingga penelitiannya merupakan penelitian populasi”.

Teknik pengambilan sampel yaitu dengan cara mengambil sampel secara keseluruhan tanpa memperhatikan strata yang ada dalam anggota tersebut karena berkedudukan yang sama dari populasi yang diteliti, sehingga penelitian ini disebut sebagai penelitian populasi atau penelitian sensus.

Metode penelitian yang dipergunakan dalam penelitian ini adalah metode survey yang bersifat kausalitas untuk melihat pengaruh antara variabel bebas terhadap variabel terikat dengan membagi variable -variabel penelitian ini ke dalam variabel bebas yaitu kompetensi guru $(\mathrm{X})$ serta variabel terikat yaitu prestasi siswa di SMK Pariwisata YAPPMI Jatibarang.

Selanjutnya untuk memperoleh hasil penelitian yang akurat diperlukan data primer dan data sekunder. Data primer adalah data yang diperoleh secara langsung yang telah diperiksa validitas dan kelengkapannya, kemudian data tersebut diklasifikasikan dan dicatat secara sistematis. Data sekunder adalah data yang diterbitkan atau digunakan oleh organisasi yang bukan merupakan pengolahnya.

\section{Definisi Konseptual dan Operasional Variabel}

Kompetensi guru adalah kegiatan atau cara untuk mendorong gejolak dalam diri manusia agar mau berperilaku, bekerja secara optimal untuk memenuhi kebutuhan atau tujuan yang telah ditentukan. Prestasi siswa adalah merupakan hasil pekerjaan yang mempunyai hubungan kuat dengan tujuan strategis organisasi, kepuasan konsumen, dan memberikan kontribusi pada ekonomi. Dijelaskan dala penelitian sebelumnya bahwa :

1. Diasty Widar Hapsari1, Arif Partono Prasetio,dan Drs, M.M, CPHR (2017) Penelitian ini bertujuan mengukur pengaruh tingkat kompetensi guru di SMK Negeri 2 Bawang terhadap prestasi belajar siswa. Penelitian dilakukan di Kota Bawang, Jawa Tengah dengan menggunakan 250 responden siswa. Seperti diketahui bahwa salah satu tujuan proses belajar mengajar adalah adanya peningkatan pemahaman siswa yang pada akhirnya akan terefleksi pada prestasi mereka. Salah satu faktor penting untuk meningkatkan prestasi siswa adalah kompetensi pengajar. Pengajar yang kurang memiliki kompetensi di bidangnya dapat mengganggu pencapaian sasaran tersebut. Pengumpulan data dilakukan dengan kuesioner yang berisi 25 pertanyaan. Data penelitian ini memenuhi uji asumsi klasik yang berarti bisa digunakan untuk menganalisi pengaruh variabel independen dengan menggunakan analisis regresi sederhana. Kompetensi guru ternyata berpengaruh positif dan signifikan terhadap prestasi siswa dengan nilai R2 sebesar 0.129 dengan Sig. 0.000. Hal ini memperlihatkan bahwa organisasi pendidikan menengah perlu senantiasa melakukan pengembangan kompetensi tenaga pengajarnya. Dengan kompetensi yang selalu diperbaharui dan disesuaikan dengan perkembangan kebutuhan pendidikan terkini, para pengajar memiliki bekal lebih baik untuk membantu anak didiknya dalam mencapai prestasi yang membanggakan.

2. Randi Tampubolon (2017) Penelitian ini bertujuan mengukur pengaruh tingkat kompetensi guru di SMP St.Maria Kabanjahe terhadap prestasi belajar siswa. Penelitian dilakukan di Kota Kabanjahe , Sumatra Utara dengan menggunakan 250 responden siswa. Seperti diketahui bahwa salah satu tujuan proses belajar mengajar adalah adanya peningkatan pemahaman siswa yang pada akhirnya akan terefleksi pada prestasi mereka. Salah satu faktor penting untuk meningkatkan prestasi siswa adalah kompetensi pengajar. Pengajar yang kurang memiliki kompetensi di bidangnya dapat mengganggu pencapaian sasaran tersebut. Pengumpulan data dilakukan dengan kuesioner yang berisi 25 pertanyaan. Data penelitian ini memenuhi uji asumsi klasik yang berarti bisa digunakan untuk menganalisi pengaruh variabel independen dengan menggunakan analisis regresi sederhana. Hal ini memperlihatkan bahwa organisasi pendidikan menengah perlu senantiasa melakukan pengembangan kompetensi tenaga pengajarnya. Dengan kompetensi yang selalu diperbaharui dan disesuaikan dengan perkembangan kebutuhan pendidikan terkini, para pengajar memiliki bekal lebih baik untuk membantu anak didiknya dalam mencapai prestasi yang membanggakan.

3. Lero, Yeremias Wunda (2013) Pengaruh Kompetensi dan Perilaku Guru terhadap Prestasi Belajar Siswa Sekolah Menengah Atas dan Sekolah Menengah Kejuruan di Kabupaten Sumba Barat Daya. Masters thesis, Universitas Terbuka. Salah satu tujuan pembentukan Negara Indonesia adalah untuk mencerdaskan Bangsa. 
Kementerian Pendidikan Nasional dan jajarannya dari pusat hingga ke daerah-daerah adalah Untuk mewujudkan tujuan negara tersebut. Guru sebagai salah satu komponen penting yg diharapkan memiliki kompetensi yang memadai. Kompetensi diharapkan dapat membentuk perilaku yang profesional dan perilaku profesional diharapkan dapat meningkatkan kinerja. Salah satu indikator kinerja guru adalah hasil belajar siswa. Prestasi (lulusan) siswa SMP, SMA dan SMK di Sumba Barat Daya sejak tahun 2009/2010 hingga 2011/2012 semakin meningkat mencapai $100 \%$. Tentunya prestasi ditentukan oleh banyak variabel, tetapi dalam penelitian ini variabel yang diteliti adalah kompetensi guru, perilaku guru baik perilaku dalam proses kegiatan belajar mengajar maupun perilaku dalam evaluasi belajar. Masalah dalam penelitian ini adalah: Seberapa besar pengaruh kompetensi Guru atas perilaku guru dalam proses KBM terhadap prestasi belajar siswa. Seberapa besar pengaruh kompetensi Guru atas perilaku guru dalam proses Evaluasi terhadap pre stasi belajar siswa. Seberapa besar pengaruh perilaku guru dalam KBM terhadap prestasi belajar siswa. Seberapa besar pengaruh perilaku guru dalam evaluasi terhadap prestasi belajar siswa. Seberapa besar pengaruh perilaku guru dalam KBM dan Evaluasi terhadap prestasi belajar siswa. Hasil penelitian menunjukkan bahwa Kompetensi guru berpengaruh secara parsial dan signifikan terhadap perilaku guru dalam KBM; Kompetensi guru berpengaruh secara parsial dan signifikan terhadap perilaku guru dalam evaluasi; Perilaku guru dalam PBM berpengaruh secara parsial dan signifikan terhadap prestasi siswa; Perilaku guru dalam evaluasi berpengaruh secara parsial dan signifikan terhadap prestasi siswa; Kompetensi guru, perilaku guru dalam PBM, perilaku guru dalam evaluasi berpengaruh secara simultan dan signifikan terhadap prestasi siswa. Disarankan para guru dapat meningkatkan kompetensinya sehingga dapat memperbaiki perilakunya dalam kegiatan belajar mengajar untuk meningkatkan prestasi siswa. Kompetensi guru yang perlu ditingkatkan adalah kompetensi pedagogik, kompetensi profesional, kompetensi kepribadian dan kompetensi social. Sedangkan perilaku guru dalam proses KBM ditekankan pada kemampuan guru membuka pelajaran, sikap guru dalam proses pembelajaran, penguasan bahan belajar/materi pembelajaran dan mampu menggunakan media pembelajaran. Disarankan para guru dapat meningkatkan kompetensinya sehingga dapat memperbaiki perilakunya dalam evaluasi belajar untuk meningkatkan prestasi siswa. Peningkatan perilaku guru dalam evaluasi belajar ditekankan pada evaluasi pembelajaran, kemampuan menutup kegiatan pembelajaran dan tindak lanjut.

4. Jayengsari, Reksa (2013) Pengaruh Kompetensi Guru Terhadap Prestasi Belajar Siswa Pada Mata Peljaran Akuntansi DI SMK SE-KOTA Bandung. Universitas Pendidikan Indonesia. Penelitian ini dilatarbelakangi oleh adanya Sekolah Menengah Kejuruan (SMK) program keahlian akuntansi yang memiliki nilai rata-rata UN di bawah nilai rata-rata UN kota Bandung pada tahun ajaran 2011/2012. Tujuan dari penelitian ini adalah untuk mengetahui pengaruh kompetensi guru akuntansi yang terdiri dari kompetensi pedagogik, profesional, sosial dan kepribadian terhadap prestasi belajar siswa di SMK Se-Kota Bandung. Metode yang digunakan di dalam penelitian ini adalah metode deskriptif verifikatif. Teknik pengambilan sampel dalam penelitian ini adalah teknik teknik sampel acak atau simple random sampling. Sampel yang digunakan adalah 93 siswa SMK yang tersebar di 17 SMK terdiri dari 3 SMK negeri dan 14 SMK Swasta. Untuk memperoleh data kompetensi guru diperoleh dengan cara menyebarkan angket kepada 93 siswa sedangkan prestasi belajar berasal dari nilai UAS kelas XII kompetensi produktif semester ganjil. Gambaran kompetensi pedagogik dan sosial guru akuntansi tergolong pada kategori tinggi, sedangkan kompetensi profesional dan kepribadian tergolong pada kategori sedang. Gambaran prestasi belajar siswa tergolong pada kategori sedang. Untuk menguji hipotesis dalam penelitian ini menggunakan regresi berganda dengan bantuan program SPSS V 16.0 for Windows. Hasil penelitian menunjukan keempat kompetensi guru memberikan pengaruh terhadap prestasi belajar sebesar 25,5\% sedangkan sisanya sebesar 74,5\% dipengaruhi oleh variabel lain yang tidak dimasukkan dalam penelitian ini. Hasil uji hipotesis,uji F diketahui kompetensi pedagogik,profesional,sosial dan kepribadian memiliki pengaruh dan signifikan terhadap prestasi belajar siswa. Hasil uji t diketahui kompetensi pedagogik memiliki pengaruh terhadap prestasi belajar, kompetensi profesional memiliki pengaruh terhadap prestasi belajar, kompetensi sosial memiliki pengaruh terhadap prestasi belajar dan kompetensi kepribadian memiliki pengaruh terhadap prestasi belajar. Diharapkan guru dapat meningkatkan keempat kompetensi tersebut agar tujuan dari pembelajaran berupa prestasi belajar siswa dapat tercapai secara optimal. Kata Kunci : Kompetensi Pedagogik, Kompetensi Profesional, Kompetensi Sosial, Kompetensi Kepribadian dan Prestasi Belajar.

5. Saptono Budi Sigit Santosa Suhendro (2018), Pengaruh Kompetensi Guru, Lingkungan Sekolah dan Efikasi Diri terhadap Motivasi Belajar Siswa SMP Batik Surakarta, Penelitian ini bertujuan untuk mengetahui interaksi pengaruh kompetensi guru, lingkungan sekolah dan self-efficacy secara parsial dan bersama-sama terhadap 
motivasi belajar siswa. Populasi penelitian sebanyak 303 siswa sedangkan sampel penelitian sebanyak 269 siswa dengan teknik pengambilan sampel adalah jenuh. Pengumpulan data menggunakan kuesioner dan studi pustaka. Analisis data menggunakan regresi linier berganda. Hasil penelitian diketahui nilai koefisien determinasi sebesar 0,414 artinya pengaruh kompetensi guru, lingkungan sekolah dan efikasi terhadap motivasi belajar siswa SMP Batik sebesar 41,4\% 58,6\% sedangkan variabel lain yang berpengaruh diluar model. Terdapat pengaruh kompetensi guru, lingkungan sekolah dan efikasi diri terhadap motivasi belajar di SMP Batik.

TABEL 1. Operasional Variabel.

\begin{tabular}{|c|c|c|}
\hline Variabel & Dimensi & Indikator \\
\hline $\begin{array}{l}\text { Kompetensi Guru } \\
(\mathrm{X})\end{array}$ & $\begin{array}{l}\text { Kemampuan penguasaan } \\
\text { materi }\end{array}$ & $\begin{array}{l}\text { a) Mampu menguasai substansi } \\
\text { pembelajaran } \\
\text { b) Mampu mengorganisasikan } \\
\text { materi pembelajaran } \\
\text { c) Mampu menyesuaikan materi } \\
\text { pelajaran dengan kebutuhan } \\
\text { siswa }\end{array}$ \\
\hline & $\begin{array}{l}\text { 2. Pemahaman terhadap } \\
\text { perkembangan profesi }\end{array}$ & $\begin{array}{ll}\text { a) } & \text { Mampu mengikuti } \\
& \text { perkembangan kurikulum } \\
\text { b) } & \text { Mampu mengikuti } \\
& \text { perkembangan IPTEK } \\
\text { c) Mampu menyesuaikan } & \text { permasalahan umum dalam } \\
& \text { proses belajar dan hasil } \\
\text { belajar } & \\
\text { d) Mampu mengembangkan } \\
\text { dan menggunakan berbagai } \\
\text { alat, metode dan sumber } \\
\text { belajar yang relevan (sesuia) } \\
\text { e) Mampu mengembangkan } \\
\text { bidang studi } \\
\text { f) Mampu memahami fungsi } \\
\text { sekolah }\end{array}$ \\
\hline \multicolumn{3}{|c|}{ Sumber : Peraturan Pemerintah Republik Indonesia Nomor 74 Tahun 2008} \\
\hline $\begin{array}{l}\text { Prestasi Siswa } \\
\text { (Y) }\end{array}$ & 1. Faktor intern & $\begin{array}{l}\text { a) Faktor jasmaniah } \\
\text { b) Faktor psikologis } \\
\text { c) Faktor kelelahan }\end{array}$ \\
\hline & 2. $\quad$ Faktor ekstern & $\begin{array}{l}\text { a) Faktor sosial } \\
\text { b) Faktor budaya } \\
\text { c) Faktor lingkungan }\end{array}$ \\
\hline
\end{tabular}

Sebelum dilakukan analisis data, perlu dilakukan pengujian terhadap instrumen penelitian yaitu :

1. Uji Instrumen

Analisis data merupakan suatu proses penyederhanaan data kedalam bentuk yang lebih mudah dibaca dan diinterpretasikan. Dengan menggunakan metode kuantitatif, diharapkan akan didapatkan hasil pengukuran yang lebih akurat tentang respon yang diberikan oleh responden, sehingga data yang berbentuk angka tersebut dapat diolah dengan menggunakan metode statistik.

Pengujian validitas dan reliabilitas adalah proses menguji butir-butir pertanyaan yang ada dalam sebuah angket/kuisioner, apakah isi dari butir-butir pertanyan tersebut sudah valid dan reliabel untuk mengukur faktorfaktor atau konstrak. Pengukuran dilakukan dengan menggunakan metode Reliability Analysis-Scale (Alpha) dengan bantuan program SPSS versi 22.

a. Uji Validitas

Uji validitas digunakan untuk mengukur sah atau tidaknya suatu kuesioner. Suatu kuesioner dinyatakan valid jika pertanyaan pada kuesioner mampu mengungkapkan sesuatu yang akan diukur untuk kuesioner tersebut (Ghozali, 2016). 
Hasil uji validitas dapat dilihat pada hasil output di kolom "Corrected Item-Total Correlation". Angka hasil pada kolom tersebut disebut r-hasil. Dikatakan valid jika r-hasil adalah positif dan lebih besar dari r-tabel ( $r$-hasil positif $>r$-tabel).Jika ternyata ada pertanyaan yang tidak valid, maka pertanyaan tersebut akan dibuang dan pengujian diulang kembali sampai hasilnya menunjukkan valid.

b. Uji Reliabilitas

Handal jika jawaban seorang terhadap pernyataan adalah konsisten atau stabil dari waktu kewaktu (Ghozali, 2016).

Hasil uji reliabilitas dapat dilihat pada hasil output di dalam kolom “Alpha if Item Deleted”.Angka pada kolom tersebut adalah r-hasilyang disebut alpha. Dikatakan reliabel jika skor butir berkorelasi positif dengan skor faktor, atau hasil angka alpha (r-hasil) positif dan lebih besar dari r-tabel (alpha $>$ r-tabel), atau angka alpha $>$ standar level lain yang ditentukan peneliti. Jika terdapat angka alpha yang tidak reliabel, pertanyaan dikeluarkan dan pengujian diulang kembali dengan mengambil pertanyaan-petanyaan dengan angka alpha yang reliabel.

2. Teknik Skala

Untuk mengukur data yang diperoleh dari angket/kuesioner yang terkumpul, pendapat responden atas pertanyaan diberi nilai dengan skala Likert, sebagaimana diungkapkan oleh Sugiyono (2014:134) bahwa skala Likert digunakan untuk mengukur sikap, pendapat dan persepsi seseorang atau sekelompok orang tentang fenomena sosial.

Dalam pengukurannya, setiap responden diminta pendapatnya mengenai suatu pernyataan, dengan skala penilaian dari 1 sampai dengan 5. Tanggapan positif (maksimal) diberi nilai paling besar (5) dan tanggapan negatif (minimal) diberi nilai paling kecil (1).

\section{RESULTS AND DISCUSSIONS}

Deskripsi data penelitian merupakan suatu gambaran dari data yang telah diperoleh selama penelitian dilakukan. Setelah data terkumpul semua langkah selanjutnya adalah melakukan tabulasi data, hal ini dimaksudkan untuk mengetahui tingkatan persepsi yang peneliti teliti yaitu kompetensi guru (X). Dimana setiap pernyataan berentang 1 sampai 5 dengan jumlah responden sebanyak 25 orang, akan dihitung menggunakan interval. Rata-rata tertinngi 5 dan rata-rata terendah 1 . Oleh karena itu variabel kompetensi guru $(\mathrm{X})$ dikategorikan sebagai berikut:

\begin{tabular}{lll}
\multicolumn{3}{l}{ TABEL 2. Skor Kriteria Jawaban Seluruh Responden dari Setiap Pertanyaan } \\
\hline Skor & Interval Kriteria & \\
\hline 5 & $945-1125$ & Sangat Setuju \\
4 & $765-945$ & Setuju \\
3 & $585-765$ & Cukup Setuju \\
2 & $405-585$ & Tidak Setuju \\
1 & $225-405$ & Sangat Tidak Setuju \\
\hline
\end{tabular}

Skor keseluruhan kuesioner dari kompetensi guru (X) dari 25 responden dapat dilihat sebagai berikut: Dari hasil jawaban kuesioner yang diberikan kepada 25 responden atas 6 pertanyaan mengenai variabel kompetensi guru $(\mathrm{X})$ dengan memberikan skor tertinggi 5 dan terendah 1. Berikut ini hasil distribusi frekuensi variabel kompetensi guru $(\mathrm{X})$ tersaji pada tabel di bawah ini:

TABEL 3. Distribusi Frekuensi Variabel Kompetensi guru $(\mathrm{X})$

\begin{tabular}{llllll}
\hline \multicolumn{5}{c}{} & \multicolumn{5}{c}{ Descriptive Statistics } \\
\hline & N & Minimum & Maximum & Sum & Std. Deviation \\
\hline B_01 & 25 & 4 & 5 & 111 & .507 \\
B_02 & 25 & 3 & 5 & 106 & .523 \\
B_03 & 25 & 3 & 5 & 109 & .569 \\
B_04 & 25 & 4 & 5 & 111 & .507 \\
B_05 & 25 & 4 & 5 & 111 & .507 \\
B_06 & 25 & 4 & 5 & 110 & .500 \\
B_07 & 25 & 3 & 5 & 111 & .583 \\
B_08 & 25 & 4 & 5 & 112 & .510 \\
B_09 & 25 & 3 & 5 & 102 & .572 \\
Valid N (listwise) & & 25 & 993 & \\
\hline
\end{tabular}


Dilihat dari tabel 4.4 di atas, menunjukkan bahwa nilai skor keseluruhan kuesioner kompetensi guru $(\mathrm{X})$ yang telah dijawab oleh responden sebesar 993 artinya dapat disimpulkan masuk dalam kategori sangat setuju/sangat baik.

Berikut ini hasil Analisis Statistik Deskriptif variabel kompetensi guru $(\mathrm{X})$ tersaji pada tabel di bawah ini:

\begin{tabular}{lll} 
TABEL 4. Analisis Statistik Deskriptif & Variabel Kompetensi Guru (X) \\
\hline $\mathrm{N}$ & Valid & 25 \\
Mean & Missing & 26 \\
Std. Error of Mean & & 39.72 \\
Median & .782 \\
Mode & 40.00 \\
Std. Deviation & 37 a \\
Variance & 3.911 \\
Range & 15.293 \\
Minimum & 20 \\
Maximum & 32 \\
Sum & 52 \\
Percentiles & 5 & 993 \\
& & 32.90 \\
a. Multiple modes exist. The smallest value is shown
\end{tabular}

Hasil analisis statistik deskriptif variabel kompetensi guru $(\mathrm{X})$ dengan menggunakan skala teoritik 5\% sampai dengan 95\% diperoleh skor rata-rata (mean) sebesar 39,72, nilai tengah (median) sebesar 40,00, nilai standar deviasi sebesar 3,911, nilai variansi sebesar 15,293, nilai minimum sebesar 32 dan nilai maksimum sebesar 52.

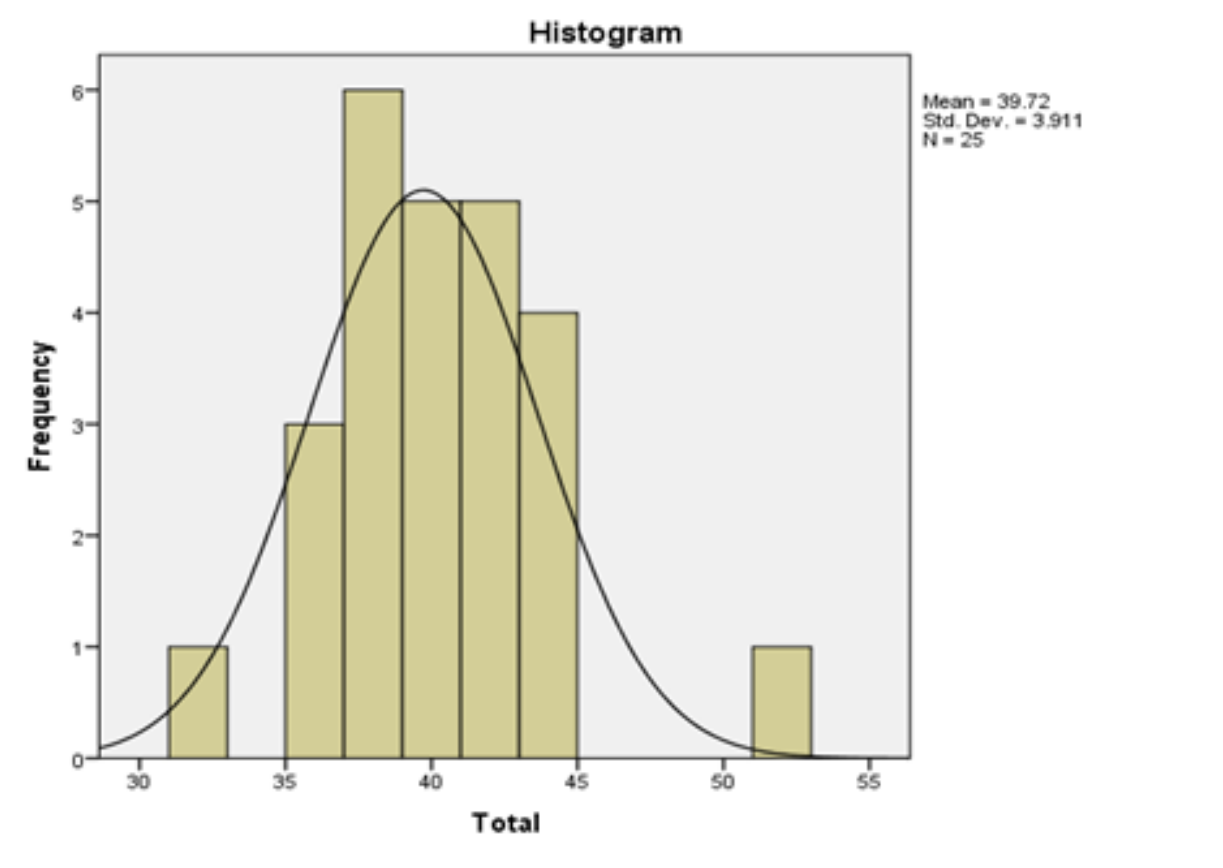

Gambar 1. Histogram Variabel Kompetensi Guru (X)

Hasil penelitian variabel prestasi siswa (Y) diperoleh melalui pengisian kuisioner yang disebarkan kepada 25 orang responden yang dijadikan sebagai sampel. Dimensi yang digunakan pada variabel prestasi siswa (Y). Pertanyaan - pertanyaan yang terdapat pada kuisioner dibuat sendiri oleh peneliti dengan mengacu pada kisi-kisi instrumen yang ada.

Data rekapitulasi / tabulasi jawaban responden mengenai variabel prestasi siswa dan pegawai (Y) seperti terlihat pada tabel (data terlampir). Total skor variabel prestasi siswa (Y) yaitu sebesar 653.

Berikut ini adalah hasil analisis uji validitas dan reliabilitas mengenai variabel prestasi siswa $(\mathrm{Y})$ :

a. Uji Validitas Variabel Prestasi siswa (Y) 
Instrumen yang valid berarti alat ukur yang digunakan dapat mengungkap data dari variabel yang diteliti secara tepat.

Kriteria:

1. Jika rhitung $>$ rtabel, maka pernyataan tersebut valid

2. Jika rhitung $<$ rtabel, maka pernyataan tersebut tidak valid

Dimana untuk df $=\mathrm{n}-1=25-1=24$ dan $\alpha=5 \%$, berdasarkan tabel koefesien korelasi $\mathrm{r}$ product moment maka diperoleh rtabel $=0.3882$.

Hasil perhitungan validitas instrumen menggunakan program SPSS 22.0 for Windows diperoleh:

TABEL 5. Uji Validitas Prestasi Siswa $(\mathrm{Y})$

\begin{tabular}{lllll}
\hline & $\begin{array}{l}\text { Scale Mean if } \\
\text { Item Deleted }\end{array}$ & $\begin{array}{l}\text { Scale } \\
\text { Variance if } \\
\text { Item Deleted }\end{array}$ & $\begin{array}{l}\text { Corrected Item- } \\
\text { Total Correlation }\end{array}$ & $\begin{array}{l}\text { Cronbach's } \\
\text { Alpha if Item } \\
\text { Deleted }\end{array}$ \\
\hline P_01 & 21.76 & 4.607 & .654 & .776 \\
P_02 & 21.76 & 4.857 & .662 & .779 \\
P_03 & 21.68 & 4.810 & .538 & .800 \\
P_04 & 21.72 & 4.960 & .400 & .833 \\
P_05 & 21.80 & 4.417 & .651 & .775 \\
P_06 & 21.88 & 4.527 & .647 & .777 \\
\hline
\end{tabular}

TABEL 6.

\begin{tabular}{llll}
\hline $\begin{array}{l}\text { No. } \\
\text { Butir }\end{array}$ & rhitung & rtabel & Status \\
\hline 1. & 0.654 & 0.3882 & Valid \\
2. & 0.662 & 0.3882 & Valid \\
3. & 0.538 & 0.3882 & Valid \\
4. & 0.400 & 0.3882 & Valid \\
5. & 0.651 & 0.3882 & Valid \\
6. & 0.647 & 0.3882 & Valid \\
\hline
\end{tabular}

Berdasarkan hasil perhitungan diperoleh untuk setiap pernyataan nilai $\eta_{\text {hitung }}>r_{\text {tabel }}$ sehingga semua pernyataan untuk variabel prestasi siswa (Y) adalah valid.

b. Uji Reliabilitas Variabel Prestasi Siswa (Y)

Instrumen yang reliabel adalah instrumen yang bila digunakan beberapa kali untuk mengukur obyek yang sama akan menghasilkan data yang sama. suatu instrument dikatakan reliabel apabila memiliki nilai Alpha Cronbach $>$ 0,60 .

Hasil uji reliabilitas variabel prestasi siswa (Y) dapat dilihat pada tabel 4.9 di bawah ini:

TABEL 7. Uji Reliabilitas Variabel Prestasi Siswa (Y)

\begin{tabular}{ll}
\hline $\begin{array}{l}\text { Cronbach's } \\
\text { Alpha }\end{array}$ & N of Items \\
\hline .819 & 6 \\
\hline
\end{tabular}

Dengan melihat hasil perhitungan di atas diperoleh nilai Alpha Cronbach $>0,60$ atau 0,819 $>0,60$ sehingga variabel prestasi siswa (Y) adalah reliabel.

c. Analisis Statistik Deskriptif Variabel Prestasi Siswa (Y)

Deskripsi data penelitian merupakan suatu gambaran dari data yang telah diperoleh selama penelitian dilakukan. Setelah data terkumpul semua langkah selanjutnya adalah melakukan tabulasi data, hal ini dimaksudkan untuk mengetahui tingkatan persepsi yang peneliti teliti yaitu prestasi siswa (Y). Dimana setiap pernyataan berentang 1 sampai 5 dengan jumlah responden sebanyak 25 orang, akan dihitung menggunakan interval. Rata-rata tertinngi 5 dan rata-rata terendah 1 . Oleh karena itu variabel prestasi siswa (Y) dikategorikan sebagai berikut:

TABEL 8. Skor Kriteria Jawaban Seluruh Responden dari Setiap Pertanyaan

\begin{tabular}{lll}
\hline Skor & Interval & Kriteria \\
\hline 5 & $630-750$ & Sangat Setuju \\
4 & $510-630$ & Setuju
\end{tabular}




\begin{tabular}{lll}
3 & $390-510$ & Cukup Setuju \\
2 & $270-390$ & Tidak Setuju \\
1 & $150-270$ & Sangat Tidak Setuju \\
\hline
\end{tabular}

Skor keseluruhan kuesioner dari prestasi siswa $(\mathrm{Y})$ dari 25 responden dapat dilihat sebagai berikut: Dari hasil jawaban kuesioner yang diberikan kepada 25 responden atas 6pertanyaan mengenai variabel prestasi siswa $(Y)$ dengan memberikan skor tertinggi 5 dan terendah 1. Berikut ini hasil distribusi frekuensi variabel prestasi siswa $(\mathrm{Y})$ tersaji pada tabel di bawah ini:

TABEL 9. Distribusi Frekuensi Variabel Prestasi Siswa (Y)

\begin{tabular}{llllll}
\hline \multicolumn{7}{c}{} & \multicolumn{5}{c}{ Descriptive Statistics } & Std. Deviation \\
\hline & N & Minimum & Maximum & Sum & .569 \\
\hline P_01 & 25 & 3 & 5 & 109 & .490 \\
P_02 & 25 & 4 & 5 & 109 & .583 \\
P_03 & 25 & 3 & 5 & 111 & .645 \\
P_04 & 25 & 3 & 5 & 110 & .627 \\
P_05 & 25 & 3 & 5 & 108 & .597 \\
P_06 & 25 & 3 & 5 & 106 & \\
Valid N (listwise) & 25 & & & 653 & \\
\hline
\end{tabular}

Dilihat dari tabel 4.8 di atas, menunjukkan bahwa nilai skor keseluruhan kuesioner kuesioner prestasi siswa (Y) yang telah dijawab oleh responden sebesar 653 artinya dapat disimpulkan masuk dalam kategori sangat setuju/sangat baik.

Berikut ini hasil Analisis Statistik Deskriptif variabel prestasi siswa $(\mathrm{Y})$ tersaji pada tabel di bawah ini:

TABEL 10. Analisis Statistik Deskriptif Variabel Prestasi Siswa (Y)

\begin{tabular}{lll}
\hline $\mathrm{N}$ & Valid & 25 \\
Mean & Missing & 26 \\
Std. Error of Mean & & 26.12 \\
Median & & .511 \\
Mode & & 26.00 \\
Std. Deviation & & 26 \\
Variance & 2.555 \\
Range & 6.527 \\
Minimum & 11 \\
Maximum & 19 \\
Sum & & 30 \\
Percentiles & & 653 \\
& 5 & 20.20 \\
\hline
\end{tabular}

Hasil analisis statistik deskriptif variabel prestasi siswa dan pegawai $(\mathrm{Y})$ dengan menggunakan skala teoritik 5\% sampai dengan $95 \%$ diperoleh skor rata-rata (mean) sebesar 26.12, nilai tengah (median) sebesar 26,00, nilai standar deviasi sebesar 2,555, nilai variansi sebesar 6,527, nilai minimum sebesar 19 dan nilai maksimum sebesar 30 .

Hasil analisis korelasi kompetensi guru dengan prestasi siswa terlihat pada Tabel 11 berikut ini :

TABEL 11. Analisis Korelasi Kompetensi Guru dengan Prestasi siswa

\begin{tabular}{llll}
\hline & & Kompetensi Guru & Prestasi Siswa \\
\hline \multirow{2}{*}{ Kompetensi } & Pearson Correlation & 1 & $.503^{*}$ \\
Guru & Sig. (2-tailed) & & .010 \\
& $\mathrm{~N}$ & 25 & 25 \\
\multirow{3}{*}{ Prestasi Siswa } & Pearson Correlation & $.503^{*}$ & 1 \\
& Sig. (2-tailed) & .010 & \\
& $\mathrm{~N}$ & 25 & 25 \\
\hline & *. Correlation is significant at the 0.05 level (2-tailed).
\end{tabular}

Berdasarkan data pada tabel tersebut, korelasi kompetensi guru dengan prestasi siswa yaitu sebesar 0,503 , nilai korelasi tersebut berada pada daerah sedang $(0,40-0,599=$ sedang $)$ atau dapat dikatakan bahwa korelasi atau hubungan kompetensi guru dengan prestasi siswa mempunyai tingkat hubungan sedang. Jika kompetensi guru baik maka prestasi siswa akan baik, demikian sebaliknya. 
Analisis regresi linier mengenai pengaruh kompetensi guru $(\mathrm{X})$ terhadap prestasi siswa $(\mathrm{Y})$ diperoleh hasil sebagai berikut :

1. Model Summary

Hasil analisis regresi liner model summary terlihat pada Tabel 12 berikut ini :

TABEL 12. Analisis Regresi Linier Model Summary.

\begin{tabular}{lllll}
\hline Model & $\mathbf{R}$ & R Square & $\begin{array}{l}\text { Adjusted R } \\
\text { Square }\end{array}$ & $\begin{array}{l}\text { Std. Error of the } \\
\text { Estimate }\end{array}$ \\
\hline 1 & $.503 \mathrm{a}$ & .253 & .220 & 2.348 \\
\hline \multicolumn{4}{c}{ a. Predictors: (Constant), Kompetensi Guru }
\end{tabular}

Coefficients Hasil keluaran nilai koefisien determinasi (R Square atau R2) sebesar 0,220. Nilai tersebut menunjukan kemampuan variabel kompetensi guru $(\mathrm{X})$ memiliki pengaruh dalam menjelaskan variansi pada variabel prestasi siswa $(\mathrm{Y})$ yaitu sebesar $22 \%$ dan sisanya sebesar $78 \%$ dipengaruhi oleh faktor lain (e) yang tidak diikutsertakan dalam penelitian ini.

Hasil analisis regresi linier model coefficients terlihat pada Tabel 13 berikut ini :

TABEL 13. Analisis Regresi Linier Model Coefficients.

\begin{tabular}{|c|c|c|c|c|c|}
\hline \multirow[t]{2}{*}{ Model } & \multicolumn{2}{|c|}{$\begin{array}{l}\text { Unstandardized } \\
\text { Coefficients }\end{array}$} & $\begin{array}{l}\text { Standardized } \\
\text { Coefficients }\end{array}$ & \multirow[t]{2}{*}{ t } & \multirow[t]{2}{*}{ Sig. } \\
\hline & B & Std. Error & Beta & & \\
\hline (Constant) & 12.777 & 4.891 & & 2.612 & .016 \\
\hline Kompetensi Guru & .342 & .123 & .503 & 2.790 & .010 \\
\hline
\end{tabular}

a. Dependent Variable: Prestasi Siswa

Berdasarkan data pada tabel di atas yang digunakan untuk membuat persamaan regresi linear yaitu besaran koefisien yang terdapat pada kolom unstandardized coefficients bagian B, sehingga diperoleh persamaan regresi linear sebagai berikut :

$$
\mathrm{Y}=12,777+0,345 \mathrm{X}+\mathrm{e}
$$

Dari persamaan regresi linier tersebut dapat dideskripsikan sebagai berikut :

1. Nilai koefisien sebesar 12,777 adalah nilai koefisien prestasi siswa $(\mathrm{Y})$ saat kompetensi guru $(\mathrm{X})$ sama dengan nol (0).

2. Nilai sebesar 0,345 pada koefisien $X$ yaitu jika kompetensi guru $(X)$ naik sebesar 1 satuan unit skor, maka prestasi siswa $(\mathrm{Y})$ akan naik sebesar 0,345

3. Nilai e adalah faktor lain yang tidak di ikutsertakan dalam penelitian

\section{Model Anova}

Untuk menyatakan apakah variabel bebas (independentvariable) berpengaruh atau tidak berpengaruh terhadap variabel terikat (dependentvariable) peneliti menggunakan kriteria signifikansi $\mathrm{F}$, yaitu dengan membandingkan nilai signifikansi Fhitung dengan alpha. Dalam menjelaskan koefisien F garis regresi pada penelitian ini, nilai alpha ditetapkan sebesar 0,05 atau 5\% $(\alpha=5 \%)$. Hasil keluaran regresi linier model anova terlihat pada Tabel 14 berikut ini :

TABEL 14. Analisis Regresi Linier Model Anova.

\begin{tabular}{lllllll}
\hline Model & & df & Mean Square & F & Sig. & $\begin{array}{l}\text { Sum of } \\
\text { Squares }\end{array}$ \\
\hline 1 & & & 1 & 42.925 & 7.784 & $.010 \mathrm{~b}$ \\
& Regression & 42.925 & 23 & 5.515 & & \\
& Residual & 126.835 & 24 & & & \\
& Total & 169.760 & 24 & & & \\
\hline
\end{tabular}

a. Dependent Variable: Prestasi Siswa

b. Predictors: (Constant), Kompetensi Guru

Berdasarkan data pada tabel tersebut diperoleh nilai signifikansi F sebesar 0,010 (P-value) artinya bahwa variabel kompetensi guru $(\mathrm{X})$ berpengaruh signifikan terhadap variabel prestasi siswa $(\mathrm{Y})$. Atau dengan memperhatikan nilai Fhitung $(7,784)$ yang mempunyai nilai lebih besar dari nilai Ftabel $(3,40)$ atau 7,784> 4,26 yang berarti bahwa variabel kompetensi guru $(\mathrm{X})$ berpengaruh signifikan terhadap variabel prestasi siswa $(\mathrm{Y})$.

Hipotesis Statistik 
Uji t dilakukan untuk menunjukan apakah variabel independen mempunyai pengaruh yang signifikan terhadap variabel dependen. Hasil pengujian hipotesis penelitian dengan menggunakan uji t sebagai berikut:

Ketentuan pengujian:

- Jika thitung $>$ ttabel $0,05(\mathrm{dk}=\mathrm{n}-1)$, maka Ho ditolak Ha diterima.

- Jika thitung $<$ ttabel 0,05 ( dk $=\mathrm{n}-1)$, maka Ho diterima Ha ditolak.

- Menghitung besarnya angka thitung dengan $\alpha=0,05 \mathrm{dan} \mathrm{dk}=\mathrm{n}-\mathrm{k}-1=24$, jadi ttabel $=2,064$.

Hasil pengujian hipotesis penelitian dengan menggunakan uji t sebagai berikut:

$\mathrm{H} 0=$ Tidak terdapat pengaruh antara kompetensi guru terhadap prestasi siswa

$\mathrm{Ha}=$ Terdapat pengaruh antara kompetensi guru terhadap prestasi siswa

Berikut ini adalah hasil pengujian hipotesis) dengan menggunakan SPSS versi 22.0 for windows:

TABEL 15. Hasil Uji Hipotesis.

\begin{tabular}{llllll}
\hline Model & \multicolumn{2}{l}{$\begin{array}{l}\text { Unstandardized } \\
\text { Coefficients }\end{array}$} & $\begin{array}{l}\text { Standardized } \\
\text { Coefficients }\end{array}$ & \multirow{2}{*}{ Sig. } \\
\cline { 2 - 4 } & B & Std. Error & Beta & & \\
\hline (Constant) & 12.777 & 4.891 & & 2.612 & .016 \\
Kompetensi Guru & .342 & .123 & .503 & 2.790 & .010 \\
\hline
\end{tabular}

a. Dependent Variable: Prestasi Siswa

Berdasarkan Tabel 4.14 dapat dilihat bahwa hasil perhitungan koefisien untuk Uji t adalah sebagai berikut : Nilai thitung pada variabel kompetensi guru (X) thitung 2,790 > ttabel 2,064 dan dengan tingkat signifikansi $0,010<0,05$ maka Ha diterima artinya kompetensi guru berpengaruh positif dan signifikan terhadap prestasi siswa.

\section{RESULTS AND DISCUSSIONS}

Pembahasan metodologi bahwa berdasarkan analisis statistik di atas maka hasil penelitian mengenai pengaruh kompetensi guru terhadap prestasi siswa SMK Pariwisata YAPPMI Jatibarang Indramayu dapat diinterpretasikan sebagai berikut: Pelaksanaan kompetensi guru di SMK Pariwisata YAPPMI Jatibarang Indramayu.

Hasil rekapitulasi skor jawaban responden mengenai kompetensi guru pada SMK Pariwisata YAPPMI Jatibarang Indramayu adalah sebesar 993, data tersebut berada pada daerah sangat baik $(945-1125=$ sangat setuju ), artinya kompetensi guru sudah sangat baik. Prestasi siswa di SMK Pariwisata YAPPMI Jatibarang Indramayu.

Hasil rekapitulasi skor jawaban responden mengenai prestasi siswa pada SMK Pariwisata YAPPMI Jatibarang Indramayu sebesar 653 data tersebut berada pada daerah sangat baik $(630-750=$ sangat setuju $)$ artinya tingkat prestasi siswa berada pada tingkat yang baik.Pengaruh kompetensi guru Terhadap prestasi siswa pada SMK Pariwisata YAPPMI Jatibarang Indramayu.

Hasil uji statistik pada variabel kompetensi guru terhadap prestasi siswa dan pegawai menunjukkan bahwa Nilai R Square sebesar 0,220 atau $22 \%$ artinya ada pengaruh kompetensi guru terhadap prestasi siswa dan sisanya 78 $\%$ adalah variabel diluar penelitian.

Nilai thitung kompetensi guru $(\mathrm{X})$ lebih besar dari ttabel $(2,790>2,064)$ atau tingkat signifikansi thitung lebih kecil dari nilai alpha $(0,010<0,05)$, dengan demikian bahwa terjadi penolakan $\mathrm{H} 0$ atau penerimaan $\mathrm{Ha}$ yang berarti menunjukan adanya pengaruh variabel kompetensi guru $(\mathrm{X})$ secara positif dan signifikan terhadap variabel prestasi siswa $(\mathrm{Y})$.

\section{CONCLUSIONS}

Kesimpulan dari hasil penelitian mengenai pengaruh kompetensi guru terhadap prestasi siswa di SMK Pariwisata YAPPMI Jatibarang Indramayu adalah:

1. Kompetensi guru yang ada pada SMK Pariwisata YAPPMI Jatibarang Indramayu berada pada kondisi sangat baik. Hasil rekapitulasi skor jawaban responden mengenai kompetensi guru pada SMK Pariwisata YAPPMI Jatibarang Indramayu adalah sebesar 993 data tersebut berada pada daerah sangat setuju $(945-1125=$ sangat setuju),

2. Prestasi siswa dan pegawai di SMK Pariwisata YAPPMI Jatibarang Indramayu berada pada kondisi sangat baik. Hasil rekapitulasi skor jawaban responden mengenai prestasi siswa pada SMK Pariwisata YAPPMI Jatibarang Indramayu sebesar 653 data tersebut berada pada daerah sangat baik $(630-750=$ sangat setuju $)$ 
3. Hasil uji statistik pada variabel kompetensi guru terhadap prestasi siswa menunjukkan bahwa Nilai R Square sebesar 0,220 , atau $22 \%$ artinya ada pengaruh kompetensi guru terhadap prestasi siswa dan sisanya $78 \%$ adalah variabel diluar penelitian. Nilai thitung kompetensi guru(X) lebih besar dari ttabel $(2,790>2,064)$ atau tingkat signifikansi thitung lebih kecil dari nilai alpha $(0,010<0,05)$, dengan demikian bahwa terjadi penolakan $\mathrm{H} 0$ atau penerimaan $\mathrm{Ha}$ yang berarti menunjukkan adanya pengaruh variabel kompetensi guru $(\mathrm{X})$ secara positif dan signifikan terhadap variabel prestasi siswa $(\mathrm{Y})$.

\section{REFERENCES}

Arikunto Suharsimi. 2012. Manajemen Penelitian Edisi Baru. Jakarta: Rineka Cipta

Cogen, Victor. 2006. Melejitkan Prestasi Anak. Bandung: How Press.

Daryanto. 2013. Media Pembelajaran, Yogyakarta: Gava media

Diasty Widar Hapsari1, Arif Partono Prasetio, dan Drs, M.M, CPHR .2017. Penelitian ini bertujuan mengukur pengaruh tingkat kompetensi guru di SMK Negeri 2 Bawang terhadap prestasi belajar siswa

Harjati. 2008. Prestasi Belajar .Diambil dari Definisipengertian.com/2012/pengertian-definisi-prestasi.html

Hamdani. 2011. Strategi Belajar Mengajar. Bandung: PustakaSetia

Hetika. 2008. Prestasi Belajar. Diambil dari http://www.poltas.ac.id

Musfah, Jejen. 2011. Peningkatan Kompetensi Guru: MelaluiPelatihandanSumberBelajarTeoridanPraktik. Jakarta: Kencana

Marwisni Hasan. 2016. Memacu Masyarakat dalam Berprestasi. Jakarta: Gramedia.

Peraturan Pemerintah Republik Indonesia Nomor 74 Tahun 2008 Tentang Guru

Randi Tampubolon (2017) Penelitian ini bertujuan mengukur pengaruh tingkat kompetensi guru di SMP St.Maria Kabanjahe terhadap prestasi belajar siswa

Slameto. 2013. Belajar dan Faktor-Faktor yang Mempengaruhinya. Jakarta: PT Bina Aksara.

Sugiyono, 2014. Statistik Untuk Penelitian, Bandung: Alfabeta.

Sukmadinata, N.Sy. 2006. Pengembangan Kurikulum: Teori dan Praktik. Bandung: Rosdakarya

Sumadi Suryabrata. 2006. Psikologi Pendidikan. Jakarta: PT Raja Grafindo Persada.

Suprihatiningrum, Jamil. 2013. Guru Profesional: PedomanKinerja, Kualifikasi, dan Kompetensi Guru.Jogjakarta: Ar-Ruzz Media

Sumiati, Sri. 2009.Pengaruh Motivasi Belajar, Kompetensi Guru dan Fasilitas Belajar TerhadapPrestasi Belajar Akuntansi pada Siswa Kelas XII Ilmu Sosial di SMA Teuku Umar Semarang. SkripsiUNNES

Syaiful Bahri Djamarah dan Azwan Zain. 2013. Strategi Belajar Mengajar.Jakarta: PT Rineka Cipta. Hal. 106

Undang-undang Republik Indonesia Nomor 14 Tahun 2005 tentang Guru dan Dosen.

Undang-undang Republik Indonesia Nomor 20 Tahun 2003 Tentang Sistem Pendidikan Nasional,

Tohirin. 2008. Psikologi Pembelajaran Pendidikan Agama Islam. Jakarta: Rineka Cipta 